Portland State University

PDXScholar

1973

\title{
Student Perceptions of the Chemawa Alcohol Education Center
}

Carol Colley

Portland State University

Follow this and additional works at: https://pdxscholar.library.pdx.edu/open_access_etds

Part of the Social Work Commons

Let us know how access to this document benefits you.

Recommended Citation

Colley, Carol, "Student Perceptions of the Chemawa Alcohol Education Center" (1973). Dissertations and Theses. Paper 1607.

https://doi.org/10.15760/etd.1606

This Thesis is brought to you for free and open access. It has been accepted for inclusion in Dissertations and Theses by an authorized administrator of PDXScholar. Please contact us if we can make this document more accessible: pdxscholar@pdx.edu. 


\section{ABSTRACT}

This paper was a study of the student perceptions of the Chemawa Alcohol Education Center at Chemawa Indian School including a review of the literature on adolescent drinking, Indian youth in particular. Students who entered the CAEC building during the week of November 1421, 1972, were individually interviewed to determine the demographic data on the student population, patterns of participation, and student ideas about the CAEC program. It was discovered that students interviewed prefer this year's program over last year's, that students brought in for drinking violations were more involved in the counse1ing aspects of the program, and that the student group interviewed did indeed have need for a special kind of alcohol education center. The findings were inconclusive that students had ideas for significant change in the program, that the outreach of the CAEC counselors was the most important means of advertising for the program, and that there was a difference in program use by the Northwest and Alaskan students at Chemawa. 


\section{STUDENT. PERCEPTIONS OF THE \\ CHEMAWA ALCOHOL EDUCATION CENTER}

\section{by}

Carol Colley

A research report submitted in partial fulfillment of the requirements for the degree of

MASTER OF SOCIAL WORK

Portland State University

School of Social Work

1973 
APPROVED:

Arthur C. Emlen, Professor of Social Work

Stephen LaBuff, Director, Chénawa Alcohol Education Center 


\section{ACKNOWLEDGMENTS}

I wish to thank the following people for their help in the preparation of this study: Mr. Arthur Emlen, Professor and Research Advisor, Portland State Univers1ty, School of Soclal Work; Mr. Stephen LaBuff, Director, and the staff of Chemawa Alcohol Education Center; Ms. Patricla Ernstrom, Soclal Worker, Chemawa School; and Ms. Emma Gross, Educational Coordinator, School of Soclal Work Indian Education Project. And I especially wish to thank my wonderful typist, Ms. Tane Hunter. 
LIST OF TABLES

Table

Page

I Chemawa Dropout Rate: Relationship to Drinking

II Demographic Characteristics by Case

III "Drinker" Status And Program Participation by Type of Program

IV Background Characteristics And Program Participation: Comparison of Eskimos and Yakimas 
TABLE OF CONTENTS

Page

ACKNOWLEDGMENTS

LIST OF TABLES

CHAPTER

I ALCOHOL EDUCATION FOR INDIAN YOUTH 1

Adolescent Drinking 3

Alcohol Education $\quad 7$

$\begin{array}{lr}\text { Indian Alcohol Use } & 10\end{array}$

II CHEMAWA ALCOHOL EDUCATION CENTER 13

The School 13

The Center 14

The Program 16

$\begin{array}{ll}\text { III } & 19\end{array}$

Alms of Research $\quad 19$

$\begin{array}{ll}\text { Hypotheses } & 20\end{array}$

$\begin{array}{ll}\text { IV METHOD } & 24\end{array}$

Instrument $\quad 24$

$\begin{array}{ll}\text { Interview Procedure } & 25\end{array}$

$\begin{array}{ll}\text { V FINDINGS } & \mathbf{3 0}\end{array}$

Hypothesis \#1 30

Hypothesis \#2 33

Hypothesis \#3 34

Hypothesis 非 36

Hypothesis \#5 39

Hypothesis 非 $\quad 40$

VI CONCLUSIONS $\quad 42$

Discussion of Rejected Hypotheses $\quad 44$

Need for Further Research 45

$\begin{array}{ll}\text { BIBLIOGRAPHY } & 46\end{array}$

$\begin{array}{ll}\text { APPENDIX } & 50\end{array}$

CAEC Interview Schedule $\quad 51$

Criteria for Admission at Chemawa School 53

CAEC Guidelines $\quad 58$

$\begin{array}{ll}\text { CAEC Structure and Function } & 60\end{array}$ 


\section{CHAPTER I}

\section{ALCOHOL EDUCATION FOR INDIAN YOUTH}

Alcoholism and alcohol abuse are recognized problems in the United States. Alcohol is the most abused and least worried about drug now belng consumed by the public. Alcohol abuse leads to deaths by accident and by violence, contributes to disease of the liver, heart and brain, and leads to malnutrition, crime, broken familles, mental illness and poverty. Among Indian people, alcoholism 18 at an epidemic level with rates at least two times the national average (HEW, 1971).

The alcohol problem is not 1imited to adults. There have been many studies which assess the amount and kind of alcohol use and abuse by adolescents. It is clear from these studies that adolescents are using alcohol at increasingly early ages and that abuse 18 associated with problems among this age group. Adolescents mirror the alcohol use of their parents before they are legally or developmentally ready to handle the responsibility. Many of the other problems which occur during adolescence are made more acute by drinking.

Indian youth are greatly affected by both the drinking behavior of Indian adults and by their aggravated adolescent difficulties. They come from backgrounds where drinking behavior is conducive to alcoholism and where drinking is used as a mechanism for coping with the poverty, discrimination, despair and oppression that face Indian people dally. Boarding school presents another set of problems that the Indian youth must face. Racism and educational discrimination have brought the youth 
to the boarding school. There are pressures to do well in the white man's educational system as well as pressure not to abandon the trad1tional ways of the people. The youth must contend with homesickness, new rules and procedures, less freedom, a new community to become acquainted with and survive in, and increased contact with other youth with similar problems.

Alcohol education 18 seen as one means of altering the rate of alcohollsm among the adult population and the abuse of alcohol by youth. Alcohol education is not merely a personal aid in deciding the costs and benefits of drinking and in gaining as much information as possible. Youth are also the future decision makers in the country and should be armed with knowledge for adequate legislation on the topic. One author (H1rsh, 1952) states: "They must be helped to investigate and to determine what steps soclety can take to treat and care for the problem drinkers in our midst." (p. 21) With these issues in mind, states have attempted to create alcohol education programs. Oregon in 1943 was the second state, following Mississippl in 1940, to grant leglslative appropriation for alcohol education. Now most states retain committees within state boards of education that oversee this area of education in the schools. (Oregon State Department of Education, 1956)

Indian boarding schools have followed the lead of public schools in providing alcohol education within the structure of the health classes and any other class (perhaps modern problems or chemistry) where it might seem approprlate. There has been counseling offered to students who have drinking problems, of course. But the special needs of the Indian boardIng school students in regards to alcohol have not been met. Boarding 
schools are residential so that for nine months of the year, the school 1s home for these students. Parents are not avallable for guidance, and the school must be "parent" as well as teacher, enforcer of rules, and establishment. Alcohol education in this setting should be more than just a two-week unit in a health class, since the boarding school is dealing dally with hundreds of high school students in the real world. Rather than superficial education and control, the boarding school should offer preventive education, treatment if needed, and concrete, meaningful alternatives to abusive drinking.

\section{Adolescent Drinking}

In documenting the need for special alcohol education programs for youth, several articles indicate the general concern by parents, teachers, school administrators and law enforcement officials over adolescent drinking. These articles decry the amount of drinking among youth and demand greater public information as well as Increased alcohol education programs In school (Dav1d, 1962, Landers, 1964, Lang, 1964, Mullin, 1968, Oppenheim, 1961, W1lson, 1965). For the most part these articles are emotional appeals to alert others to the widespread use among youth, but add little substantive Information. Several books on alcoholism (Bacon, 1958, Wilkinson, 1970) also include a chapter dedicated to the teen-age drinking phenomenon. Here youthful drinking is seen as an attempt to gain grown-up rights and privileges, which youth are systematically denied in our soclety, to complement the grown-up responsibilities which they are expected to fulfill. One author in Alcohol and Civilization (Lucla, 1963) states that "drinking behavior provides an Ideal symbol of 
the achlevement of adult status." (p. 216) Drinking among youth is understandable but st111 cause for concern in our soctety.

Since 1947 there has been an Increasing amount of data on the drinking habits of American youth. This investigator has attempted to condense the results of the surveys done In Idaho and Utah (Pearce and Garrett, 1970), Kansas (McCluggage, 1956), Kentucky (Kane and Patterson, 1972), Massachusetts (Blacker, 1965), the Midwest (Maddox and McCall, 1964), Mississipp1 (Globett1, 1969), New Hampshire (MacKay, 1967), New Mexico (Forslund and Gustafson, 1969), New York (Chappe11, 1953), North Carolina (Alexander and Campbe11, 1967), and Oregon (1962) among hIgh school students; one study among college age students (Straus and Bacon, 1953); and one discussion of the results of two nationwide pol1s, the Purdue Opinton Panel Poll of 1958 and the Gallup Youth Study of 1961 (Maddox, 1964).

These surveys show that about two thirds of high school students In America drink at least occasionally, ranging from $23 \%$ in the Midwest to $86 \%$ in New York. There seems to be more drinking in urban areas than In rural areas and more drinking among boys than girls, but no relationship between drinking and social class or family income. Drinking tends to be temperate for the most part among youth, with heavy drinking usually seen as a problem. The percentage of youth drinking increases with age from 13 to 17 and then tends to level off at 18 or 19 . Margaret Bacon (1968), In a general review of the research, finds that:

Although these studies were made in widely separated parts of the country and as much as ten years apart, the statistics are remarkably similar... The available evidence then does not indicate that there is any marked increase in teen-age drinking. (p. 36) 
The first drink occurs at an average age of 13-14 with the range being from 12 in New Hampshire to 15 in Utah. Arthur Cain (1963), in a handbook on the use and abuse of alcohol by youth, states that the average age for beginning to drink in the United States is 17, although he might mean the onset of social drinking as a practice which is a meaning different than the age at the first drink. These studies report that the first drink is usually taken at home with the youth's parents (polls show 60\%) espectally among girls and non-delinquents (both as high as 75\%). Those who more often begin drinking with peers tend to Iive in abstinent communities or to be delinquent. Although several studies report that nearly half of the students who drink have been drunk at least once (from $27 \%$ in Kentucky to $60 \%$ in New Mexico) or high at least once (from $50 \%$ in Kentucky to $71 \%$ in New Mexico), very few youths have been drunk enough to get sick (10\%), to pass out (3-10\%), or to be arrested for drinking violations (4-5\%). Studles reporting on delinquent youths who drink show that they are more likely than students in general to abuse alcohol: drunk (60\%), high (75\%), sick (40\%), pass out (45\%) and arrested for drinking (38\%). Reasons given for drinking by high school students in general have been mainly peer pressure, liking the taste and belng curious. Delinquent reasons are more 11kely to include reasons like feeling sad, feeling angry or wanting to get drunk. Youth from abstinent communities gave reasons of peer pressure and rebellion. Kane and Patterson determined that $40 \%$ of the students In their study had alcoholic relatives, a factor which is associated by some with potentlal alcohol abuse among youth (Jessor, 1968, 1970, Pittman and Snyder, 1962). 
Thus in general the research done on adolescent drinking in the United States shows that most youth have experienced alcohol; that they are for the most part a temperate group; that they come from all raclal and soclo-economic groups; that most learn to drink with their parents' permission at home; and that most function adequately with, or at least in spite of, their alcohol use. The next step is to look at the small, but significant group of youth who have an alcohol problem or are potentially the future problem drinkers.

James MacKay (1961) looked at the case historles of twenty youth, age 13-18, who were belng treated for alcohol problems in Massachusetts. These youth had an established drinking pattern by the first year of adolescence which had become a problem to soclety as well as themselves. Mackay discovered that every one of their fathers was alcoholic and many mothers were also. Most of these fathers had left the family permanently before the youth reached adolescence, and deprivation in the home was apparent. Alcohol was the chosen means of escape since it relleved tensions, expressed hostility toward the rejecting and/or alcoholic parent, soothed the feelings of not belonging in the family, and temporarily filled the emptiness and relleved the depression in their 11ves. Some of the same factors have been sssoclated with Indian youth.

For one to four years, Kearney and Taylor (1969) studied twenty adolescents (average age 15) with at least one alcohollc parent along with a control group. The adolescents with alcoholic parents showed considerably more disturbance as evidenced by drunkenness, suicide attempts, aggression and sexual acting out. Th1s study substantlates 
the belief that parental alcoholism is a factor in emotional disturbance in the youth and is destructive.

Alexander's studies $(1964,1967,1968)$ of ablstinent communities in North Carolina show that youth in this atmosphere drink for rebellious reasons with soclal aggression which may lead to alcohollsm:

When positive peer influence to drink is lacking, the refection of parental authority is associated with frequent drinking, excessive drinking leading to extreme intoxication, and drinking for psychological reasons rather than social reasons--all of these early drinking patterns being common in histories of problem-drinkers. (1967, p. 550)

The youth find it hard to live in soclety, and they use alcohol as a means of escaping. Alcohol abuse can be found even where the parental model is abstinence and the community has falrly homogenous values.

Blane, Hill and Brown (1968) have discovered an association between drinking and feelings of allenation (normlessness and powerlessness) in the attitudes of high school students in New England. Drinking was negatively correlated with self-esteem. If youth in general use alcohol as a way of lessening feelings of allenation, then the youth of America with special feelings of allenation should have a greater chance of abusive drinking. The place of Indian youth on the fringe of society 1s Indicative of their forced allenation and could be evidence of increased potential toward problem drinking.

\section{Alcoho1 Education}

Ways in which youth have learned about alcohol include the media, peers, and family drinking patterns. It is the opinion of many that since there is a link between parent and teen-age drinking and since 
youth seem to emulate the adult Image of drinker, that youth should be given facts and consistent adult role modeling (Mackay, 1965). That 1s, there needs to be clearly defined alcohol education for all youth and alcohol counseling for youth with recognizable drinking problems, efther actual or potentlal. These opinfons have led to several books offering suggestions for better alcohol education programs in the school (H1rsh, 1952, McCarthy, 1949, 1956, Oregon, 1955, Sanders and Bloomberg, 1966).

Research related to alcohol education has ylelded some relevant data. Globett1 and Harrison (1970) made a study of Miss1ssipp1 youth to assess their attitudes toward alcohol education prior to the introduction of that subject in the school system. Nine tenths of the 440 students surveyed felt that they should have an opportunity to learn about the nature of alcohol and 1ts use. One half stated that alcohol problems existed already at their school and that alcohol education could help to overcome them. More than $1 / 2$ had never discussed alcohol use with their famlly, yet $7 / 10$ reported that alcohol was a major subject of conversation among peers. One fourth reported that they were related to an alcohollc. And the fact that they would seek advice on alcohol use from a knowledgeable, understanding and trustworthy adult, points to the fact that students need and want adult information and sensitivity in this area.

A few articles have been written about the attitudes toward alcohol education among youth who elther have or are 11kely to develop alcoholrelated problems. Garlie (1971) interviewed the youth participants at the 19th Annual Utah School of Alcohol Studies, all of which were brought 
to the week conference to learn more about alcohol. It was discovered by pre- and post-Interviews that the youth with alcohol-related problems learned factual knowledge during this week but attitudes were not measurably altered during this brief time. It was the researcher's conclusion that even youths with alcohol use in their background can learn more about alcohol, but that all real change takes more time than a week or a unft of alcohol education in health class. Garlie admitted the Iimitations of his research and felt that it only offered trends. Weir $(1967,1968)$ has written a couple of articles based on a study of high school students from the midwest with alcoholic problems in their families. Welr discovered that the students had comparable knowledge of alcohol information with other students of non-alcoholic background, but that they scored significantly different on attitudinal measures, biographical information and concepts. It was felt that this different blographical and attitudinal data should be taken into consideration in presenting the alcohol education program to these students. It was further ascertained that the most effective counselor in helping to make attitudinal change and fulfilling the needs of the students was characterized as warm, 11stening and understanding. The conclusion was drawn that the whole school should recelve alcohol education and that those with speclal needs should get more attention and guidance.

Maddox (1963) pooled the research relating to alcohol education and came to the conclusions that the right person needs to provide the information, that the message should be geared to the audience, and that the audience must be recognized as being diverse and with special needs. 
If this 18 the case among any group of high school students, it is even more so when those students come from four states, from a diversity of tribes and villages, from many kinds of backgrounds.

Indian Alcohol Use

Research relating specifically to Indlan alcohol use has been mainly anthropological or speculative studies on "primitive man." A1though most of these studies have been about the tribes of the Plains, Southwest, and British Columbia, few have been written in any form about the tribes of the Northwest or Alaska. Edwin Lemert (1954) collected most of the work done previously in his book, Alcohol and the Northwest Coast Indians. Alcohol was introduced to the Northwest Indians first by the Russians (Aleuts) and later by the Spanish, English, French and Americans who came into their lands. For many factors not fully understood today, the tribes began to use the alcohollc beverages in trading in spite of tribal reactions against its use. And later in the face of the white Invasion, removal to reservations, loss of traditional homelands, and poverty, Northwest Indlans had learned to use the alcohol to relleve feelings of depression, anger and powerlessness.

Acculturation amplified this receptivity to liquor by multiplying the sources and areas of tension and also by the weakening or destroying of the traditional formalized procedures through which aggression was expressed and given its soctal meaning. (p. 374)

Drinking, Lemert noticed, took place only in groups and on weekends with much soctal pressure to join in. This agrees with the findings of other authors (Berreman, 1956, Graves, 1967).

Vern Drilling (1970) gathered date on Indian alcoholics in 
Minneapolis which may have some applications for Indian youth as well. Drilling noticed that there were many Indians with problem drinking who were not responding to conventional treatment for white alcoholics. H1s recommendation was that a treatment program should be staffed by trained Indian counselors treating only Indian cllents. There needed to be "a framework where the Indian alcoholic could deal with his drinking problem without being forced to try to resolve his cultural conflict pattern at the same tine" (p. 46). For the Indian youth with potential alcohol abuse problems, this means that Indlan counselors should be in charge of alcohol education and counseling programs speclally designed for Indian youth.

Th1s researcher was only able to discover one work which specifically dealt with Indian youth attitudes toward drinking. George Boyce (1965) surveyed 251 Indian h1gh school students In 1964 and found that nearly all of the boys and $2 / 3$ of the girls drank before enterlng high school. About $10 \%$ had drunk with their parents, nearly $30 \%$ of the boys had drunk alone (one of the danger signals to becoming an alcohollc), and $1 / 5$ of the students had been in trouble with the law about drinking. Some of the reasons given for drinking included "kicks", peer pressure (not called a sissy), boredom, to feel happy, to forget, and to gain courage. With this study and literature review, Boyce confirms that drinking by Indian youth is qualitatively different than drinking by white youth so that study and discussion of alcohol problems must be geared differently. Boyce recommends education which relates to their needs personally, discussions of personal values, substitutive activities, and counseling for all who need or want 1t. Further that: 
Since no sure educational, restrictive, or curative methods are known, a school must engage in constant, experimental effort to develop and try out every educational means that it can create. ( $p .37$ )

And an effort must be made to encourage students to help other students with drinking problems.

In conclusion this investigator found no direct research relating to the type of alcohol education center at Chemawa School or to any similar program at an Indian boarding school or for Indian youth. The related research has shown that there is concern for students, espectally those with alcoholism in the family or with other predisposing factors toward alcohol abuse, to receive some kind of alcohol education best suited to their needs.

Chemawa School has one of the three specifically designed programs for Indian youth and is a prototype for future programs. It is important to begin to gather some research data on the overall aspects of the program. Since the Investigator had a field placement at Chemawa School and had previous experlence with the school from years past, it was decided that research should be done there, if it could be of some service to the students. Before describing the present study, it is necessary to examine the existing program at Chemawa School, the population of the school, and the reasons why these students have difficulties similar to the ones cited in the literature review. 
CHAPTER II

CHEMAWA ALCOHOL EDUCATION CENTER

The School

Chemawa Indian Boarding School is located two miles northeast of Salem, Oregon. It is the oldest continuously operated Indian school in the United States, beginning in 1880 and having 30,000 students through the years. The school facllity can accommodate 800 students and presently has just under 600 Indian, Eskimo and Aleut high school students from Oregon, Washington, Idaho and Alaska in grades 9 through 12. Although the population has been different in years past (at varlous times covering all 12 grades, belng a vocatlonal training institute and serving only Navahos), it is now fully accredited by the State of Oregon. Indian students are admitted to Chemawa from the four northwest states meeting specific criteria. (see Appendix) These students who have attempted school near the home reservation have experfenced academic fallure and soctal rejection. The reservations in the rorthwest and communities in Alasks are areas of high unemployment, malnutrition, poor health and discrimination, and the alcoholism rate among these families is high. The fact that most students themselves choose to come to Chemawa is Indicative of the fact that Indian youth are given the responsibility to make their own decisions at an earlier age than the general population. The students often find it difficult to adjust to boarding school rules and adult authorlty when they have been given the respect of an equal to adults and have many times had the responstbilities of an adult at home. 
Indian students come to boarding school with these factors in their backgrounds. Once there they must learn to deal with daily hassles without the support of their families and home communities and to live with the restrictions imposed by the school. There has been a high rate of alcohol abuse at Chemawa leading to disciplinary dismissals which had been steadily increasing until recently.

TABLE 1

CHEMAWA DROP OUT RATE

RELATIONSHIP TO DRINRING

$$
67-8 \quad 68-9 \quad 69-70 \quad 70-1 \quad 71-2 \quad 72-3
$$

number of drops due to drinking or drugs

$$
15
$$

number of disciplinary drops

$\begin{array}{llllll}24 & 16 & 72 & 112 & 50 & 30\end{array}$

total number of students leaving Chemawa (transfers Included)

$\begin{array}{lllll}32 & 39 & 126 & 267 & 166\end{array}$

The Center

The Chemawa Alcohol Education Center (CAEC) was the result of efforts of the Indian Advisory Board, the student counc1l, the faculty, the Bureau of Indian Affairs and the Indian Health Service, all of which were alarmed at the rising problem of alcohol abuse at Chemawa. A proposal was submitted to and funded by the National Institute of Mental Health to create a speclal program to contain alcohol problems on campus by means of a "guest factlity", to provide information on alcohol abuse and its effects to both students and staff, to provide ald to 
dormitory staff in the management of alcohol problems, to help to establish peer pressure against abusive drinking, and to get students involved in helping each other to raise the pride of Indian people. CAEC has been funded for three years, and this is the second year of operation.

CAEC is located in a renovated house on the Chemawa campus near the health clinic. Since it used to be an employee home, the building has a kftchen, large lfving room, bathroom, three large rooms and a garage. The living room is used as a film theatre, a place for rapping and games, a meeting room, and for activities normally found in a living room. Two of the downstairs rooms are used as a male and female "guest facilitles" or places for drunk students to sleep it off without disturbing others. The garage of the house has been made into office space for the director and secretary, and the upstairs is used as an office for the counselors. Last year CAEC was housed upstairs in a corner of the health clinic sharing space with the visiting optometrist in the day and disturbing sleeping patients at night. The CAEC staff was able to renovate the old house which was home to the Chemawa doctor when that house along with several others was determined to be more needed for student use than for staff use.

The staff at CAEC consists of director, Steve LaBuff (Blackfeet) who is himself a rehabilitated alcoholic, assistant director Vicky Belgard (Yurok), secretary Grace Chandler (Paiute), and four counselors, Archle Little (Sloux), Bill Minicke (Yakima), Art Corwin (Flathead) and Tira Andersen (Stoux). In addition to these adult counselors, there is the Important student staff which adds to this program's uniqueness. 
There are twelve student volunteers who are paid the salary of $\$ 1.60 /$ hour and work in shifts in the evenings on school days and most of the weekend. Half of these students are chosen by the staff at CAEC as people who show great interest and potential for being effective aldes with other students who come to CAEC. The other half are chosen by the student council which has the power to review and recommend the adult staff members as well. CAEC's bosses are the student councll and the all-Indlan Chemawa School Board.

\section{The Program}

At the time of the survey early in the year, one aspect of the program consisted of showing films in the dormitories and the center and giving talks to classes on alcohol education. CAEC helped to sponsor some in-service and orientation training for new and old education and guldance personnel at the beginning of the year. CAEC was becoming involved on campus through participation in meetings. By the time of the study, the student volunteers had been chosen from a 11st of 43 interested students who had signed up to work in the early months of school. During the week of the study, the student council made their cholces for the six members they wanted to serve formally for the remainder of the year, and the CAEC staff made the needed choices of the remaining six members. Many of the students Interviewed by the Investigator were among the student volunteer staff.

Informal rapping and counseling occurred at CAEC whenever people were present at the center, often in the living room or kitchen. Sometimes discussions would be sparked by the films shown there, the 
Information pamphlets laid on the shelves or the posters decorating the walls. Sometimes students came to the center with specific interests such as to learn to help a friend who drinks too much, to understand an alcoholic relative, or to learn more about a spectfic drug or alcoholic beverage. Sometimes an easy going counselor was able to begin discussions with curlous students wandering in and to engage them in serious thinking about alcohol and drugs. And of course, as the various kinds of counselors on campus discovered, CAEC staff were used as helpers with homesick or lonely students and many other non-drug-related problems.

CAEC had group counseling sessions for students identified to have drinking problems or to have special interest and desire to be in these groups. Group meetings were held at CAEC in the upstairs room led by adult and student staff members and about ten Chemawa students. Topics usually covered the effects and kinds of alcoholic beverages, alcoho11sm, alcohol abuse among Indlans, Indlan pride, problems at Chemawa and at home, and alternatives to student drinking. They were held a couple of times a week and served many students by the time of the study.

Whenever needed, the staff would ald students brought over by campus security (another student-staff organization at Chemawa) for drinking. Since drinking is against the law for minors in Oregon, c1ty police who once took drinking Chemawa students to the Juvenile Detention Hall in Salem, now call security to take them to CAEC. Security and CAEC staff patrolling at night have the alternatives of taking the drinking student to the dormitory to sleep (much as any high school student who drinks a 1ittle at a party would be treated at home) or to CAEC. E1ther way student staff are the main people involved in any on-campus movement to 
elther location (plus, if needed, the Chemawa health clinic or city JDH facility. can still be relled upon). Students remain with the drinkIng student while at CAEC also; they are the mainspring of the programs. The student volunteers are trained to come as soon as called by campus personnel and to detect potential drinking problems. They learn basic first ald and have the chance for additional training In alcoho1ism counseling by the adult staff and consultants. In addition, attempts have been made to send students out to various training sessions. The adult counselors take formal training In Alcoholism Counseling at the University of Utah with some required classwork there and some assignments done in field work at CAEC. Recently the staff, both student and adult, has participated in TV and Iive panels on student alcohol use and abuse. The student volunteers are encouraged and assisted in locatIng employment in alcoholism programs once returning home, so that the student volunteers can use CAEC as training ground for a career.

In summary, the CAEC program Includes alcohol and drug education both for students and Chemawa personnel; control and treatment for students who drink at Chemawa (guest facility); counseling for both Individuals and groups of students as requested by the students themselves and by other school sources; additional counseling on other than alcoholrelated problems; referral to other counseling services if necessary; and on-the-job training for future alcoholism counselors. 
CHAPTER III

RESEARCH

Aims of Research

Since CAEC is one of the most complete programs in existence (the only other simflar programs are at Chilocco School and Haskell Juntor College), the investigator has chosen to examine the program at Chemawa. The program was brought Into being by a large group of interested people, Including students, and everyone seemed proud of its accomplishments. But it appeared that the students who frequent the center had not been given the chance to comment on their views and perceptions of the center in action. It was felt by the CAEC staff and the researcher that it would be beneficial to the program to ask the students their opinions.

The aims of the research were to assess the students' perceptions of the services available at CAEC, the Image of the program, and the responsiveness of the staff, and the students' Ideas for changes they felt needed to be made. It was hoped that the research would provide some demographic data on the students themselves in order to examine the characteristics of the population served and why the Chemawa population needs a program different from traditional alcohol education programs in high schools. The research was also to provide some clues as to the patterns of participation among the students to give the staff some Idea of whether they should be showing more films, for example, in order to change the direction of their outreach. For this reason the researcher chose to 1 imit the research to a group of students who came to the center rather than a cross section of the school. 
It would have been possible to obtain such a cross-section or even a total sample of the Chemawa school population had it been desired since the population is contained. However, the researcher and CAEC staff were interested in the students who came, In the reasons that they came, and in how they were Involved in the program. It was thought that since the research was done so early in the year, probably few students really understood exactly what the program was. Had the general population been interviewed, the number of students with no opinion would have been great. If, Instead, those who frequented were interviewed, then more pertinent Information could be obtained more quickly and efficlently. Thus those who physically walked through the door were determined to be the sample to be interviewed.

\section{Hypotheses of Research}

It is difficult to make any predictions of what general student perceptions of CAEC would be since the data derived would be unlike a longrange empirfcal research such as an analysis of the effectiveness of the program (which would involve a full knowledge of the entire population before, during and after use of the program, that is, what are the changes in the students made by the program) or even the cross-sectional school Impressions of the program (for example, the difference between students using the program and those who know about the program but fail for whatever reason to make use of $1 t$ ). Instead, the research results obtained were for the most part from a small sample of select students who already knew about the program, but who did not have sufficient time to Judge the long-range merits of the program. 
It 18 a personal guess of this researcher that the students w111 see changes that should be made, when given a chance by an outside interviewer (1.e. one not on the staff of CAEC or working for the BIA) who 18 famillar with them (1.e. the researcher happens to be a young Indian person familiar with the Chemawa students' tribes and home areas), which they perhaps have not mentioned before to the CAEC adult staff. They w111 articulate significant changes they hope to see. Also students w111 feel that the homelike atmosphere this year is preferable to the cliniclike atmosphere of last year. It is further felt that the demographic data gathered w11l show some real differences between the high school students in the literature review and the students at Chemawa thereby showing the need for spectal alcohol education programs for this part1cular population. In sum, the data w111 show that the Chemawa student population needs a different kind of program than other high schools, prefers this year's program over last year's, and has some significant Ideas yet unassessed for changes that will be helpful to CAEC.

There are no predictions for the patterns of participation other than that those students brought in to the guest facility for drinking w11l be more 11kely to be Involved in the intensive counseling aspects of the program (especially the group counseling) and that many students w111 learn about CAEC through the outreach efforts of the staff (especlally through talks and films shown in the dormitories or classrooms). Other possible ways of finding out about CAEC are by word of mouth from students brought in to the guest facllity, word of mouth from informed Chemawa personnel, and written advertisements in the school newspaper or daily announcements. It is the opinion of the researcher that the 
personal outreach of sensitive, knowledgeable Indian alcoholism counselors to the dormitorles w111 be the most important source of information about the program based upon the findings in the 11terature review and the knowledge of the staff composition.

Finally it is felt by the researcher that there will be a difference in the use of the program between the Northwest students and the Alaskan students. It is belleved that the Northwest students have a blgger problem of alcohol abuse at home than the Alaskan students. This prediction is based on three background factors (earnings, number of siblings in the home, number of parents) gathered by Ms. Patricia Ernstrom and Dr. Y. T. Witherspoon on the composition of the student applications at Chemawa. They found in an unfinished study (Fall, 1972) that the majority of the Northwest students had broken family situations defined as one-parent or no-parent homes, and unstable home11fe. The Alaskan students, however, came from two-parent, Intact homes for the most part. It is also important to understand the differences in the backgrounds of the native groups. The Northwest Indians had more Intensive contact with white soclety, were forced to give up their ancestral lands to the European Invasion, and were relegated to small plots of land held in trust by the government known as reservations. The Alaskans were generally able to retain traditional culture Including language, dress and occupation to a greater degree than the Northwest Indians. The acculturation struggle known only too well by the Northwest tribes is falrly new to the Alaskan people. The 11terature review has made it clear that broken families, allenation and cultural clash all contribute to a higher probabllity for alcoholism and 
alcohol abuse. Therefore $1 t$ seems probable that the CAEC w111 be used

more by the Northwest students than the Alaskan students.

Therefore the hypotheses to be tested are as follows:

A measure of student perceptions and demographlc data of students attending CAEC will show that 1) there is a need for a spectal kind of alcohol education program for this particular group of students; 2) the students intervlewed prefer this year's program over last year's program; 3) the students interviewed have significant Ideas for change; 4) those students brought in for drinking violations are more involved in the counseling aspects of the program than those not brought in; 5) the outreach of the CAEC staff is the most important means of advertising for the program; and 6) the CAEC program is used more by the Northwest than the Alaskan students.

The main thrust of this research is to investigate the students' perceptions of how things are at CAEC. 
CHAPTER IV

METHOD

The population of this research is the student group at Chemawa School who use the program at CAEC by coming to the center during Its operation: In the school year, 1972-3. Th1s group will by definition contain only Indian, Eskimo and Aleut youth in grades 9-12 who are presently enrolled at Chemawa. The study sample consists of only those students who physically entered the center during the chosen week, thus eliminating any students who may use the CAEC program in another way that week (perhaps seeing a film in the dorm) or who know of and use the center, but for some reason do not come that week. This sample was not selected at random, then, but consisted of all students at: Chemawa who happened to come to CAEC during the week of November 14-21, 1973. None of the students asked for an interview refused elther the main Interview or the personal information, which was introduced as optional.

Instrument

The Instrument used (see Appendix) was an Interview schedule, all interviews being conducted by the researcher. The questions were chosen to verify or disprove the hypotheses of the researcher, to determine demographic data on the subjects, and to gather information which was requested by the CABC staff who collaborated on the questionnalre. No prior Instrumentation was discovered which could be used to determine 
these answers. The researcher chose the questions at the time which seemed to be the best way to get at the information desired.

Questions \#2d, \#6 and \#7 were plcked to provide information as to the students' perceptions of this year's program compared to last year's, the Image of the program, and their 1deas for change in the program. Questions 2d, 6 and 7 were think questions which were sometimes left for last by the students intervlewed since answers to them took a little time to formulate. Questions \#3 and \#4 were by agency request. Question \#5 also provided the means by which the students could be categor1zed as to whether or not they had been brought in to the guest facllity for drinking. The other questions, especially the optional \#8, were plcked to provide demographic information about the students which hopefully would demonstrate the needs of this group of students and provide a means of separating the Northwest from Alaskan students for verification of hypotheses.

\section{Intervlew Procedure}

The interviews were made during the week of November 14-21, 1972, plus a few in the next two weeks for students who were for whatever reason unable to be interviewed on the spot. All of the staff members had full knowledge of the reasons for the presence of the Investigator and for the questionnalre. But since different staff members worked different nights, it was necessary to remind some staff members of the purpose.

Each student who entered CAEC during the week was quietly asked if he would like to be a part of a study of CAEC. Usually the student 
required more information before he would consent to the interview. He was told that the CAEC staff wished to know what students thought of the place and what students wanted to see changed. He was given some Information about the researcher if it seemed necessary. Also after the first interview, it was possible to state that the interview would take only ten minutes or so to complete. With this information, nearly all of the students agreed to the interview immediately. A few needed a little time or encouragement from friends in order to agree to be interviewed. Most students were approached and intervlewed alone, but. some came to be interviewed in groups of two and in one case, three. The student was usually approached for the interview in the living room or kitchen. Then he was led to the office upstairs (sat in chairs) or to one of the guest facilitles (sat on tumbling mats) for the questioning. The interviewer showed a copy of the interview schedule to the student if he requested it and then asked the questions in order, writing the responses on a separate sheet of paper. Some students at this point wondered about confidentiality, and were satisfied when the researcher assured them that their names would not be divulged (other than to say that they did take the interview). They were told that those reading the results of these interviews would be more interested in the total number of students saying certain things. The questions were asked simply so that the student could make his own Inferences. \#5 was asked point by point in this way: "How have you used CAEC? Have you ever been brought in for drinking? Have you ever seen films shown by CAEC? (If no, have you ever seen films shown by CAEC in the dormitory or classroom?) Have you ever received 
Information here? Have you ever come over Just to rap with people? Have you ever talked to any of the counselors here about personal problems? Have you ever been in any groups here? (If yes, did that group ever discuss alcohol problems?) Have you ever had contact with home through any of these CAEC counselors? (Th1s was an agency request to see if there was a need for this). Have you ever used CAEC as a hangout?" A11 other questions (1-4 and 6-7) were asked just as written in the same manner during each interview.

Question \#8 was prefaced with "this next question Involves personal information and you don't have to answer it if you don't want to." Each letter $(a-f)$ was asked fust as written, and the possibilities for \#f were only mentioned when the student hesitated in answering why he drank while at school, such as, "Well, is it because you feel sad or because your friends make you or what?"

Following the intervlew, several students wished to talk at length about the interview, about personal incidents with or questions about alcohol use, about CAEC in general or about totally unrelated subjects. Consequently the ten minute interview occasionally took half an hour or longer. A couple of students wished to check the scribbles made by the researcher on their responses, and all who did gave their approval to them. Then the students were thanked for their time and were usually walked back to the main rooms of the building where they began again the activity started before the Interview while the researcher found a new victim.

During the interview the researcher attempted to be non-committal and non-judgmental about the responses, yet frlendly and willing to 
listen to any elaborations offered by the students. Only on one question was the researcher aware of any attempts to lead the Interviewee which must be discussed here. Question \#7 involved changes that they would like to see made at CAEC. It must be admitted that when the student inftially stated "no changes" or that he could not think of anything that needed to be improved, the researcher probably looked a little amazed and asked again "Are you sure? There's nothing you'd 1ike to see changed or added?" This reflects the researcher's bias that the program was set up by adults and a select group of students and that most of the student body was never consulted about their opinion so that, once given the chance, most students would really try to think of numerous changes. This influence was made obvious when interviewing two students together. Both had no Ideas for change, but when one mentioned an off-hand suggestion and the researcher sald "Yes" and wrote it down, suddenly both students began to toss out suggestions that seemed to surprise themselves.

The researcher, however, sought to maintain a non-threatening atmosphere accepting of both the abstainer and the drinker, the firsttime student to CAEC and the old-timer, and the student with few ideas. I Since there was no part of the interview which would require scoring or other form of fudgment, the researcher's blas was not a factor in the other questions.

It was most difficult once the week was past to locate students missed and interview them while maintaining the same atmosphere of the earlier interviews. Two intervlews begun at CAEC were finished at the guidance office where the researcher's field work office was located. 
Two students were not located for an interview, and the remaining five students were interviewed in their dormitory room or dormitory counselor's office. Each student was given the same prologue speech with the addition that since the researcher missed them for whatever reason, it was necessary to track them down later. Then once an Isolated room for the Interview was located, the interview proceeded In exactly the same manner as prevlously explained. These interviews were most probably unaffected by the setting, except in the case of two. One student was obviously 111 at ease during the interview and never seemed to be convinced that the researcher was not somehow checking him out since he was being interviewed by a strange adult in the counselor's office. The second student was one who had been too drunk to answer questions the night of his stop at CAEC, so the belated Interview undoubtedly was more emotion-charged than for the sober students who were interviewed in elther setting. He was goodnatured enough, just caught off guard by the Investigator.

Research bias in the tabulations was controlled for by numbering the students and not referring to them by name. One indication of this consclous effort toward being unblased is that in early tabulations it was noticed that two sisters interviewed separately had answered \#8a with contradictory answers. One stated that they had alcoholic relatives and one stated that they did not. Since this research deals only with "student perceptions", both statements were accepted as data. 
CHAPTER V

FINDINGS

Hypothesis \#1

There were 51 students interviewed. Two other students entered the center but were not intervlewed, one because he left the school too soon to be interviewed and one because he eluded the researcher. of the 51, the pertinent demographic data is described in Table 2. The demographic data can be compared with the material gained from the literature review on drinking patterns of youth and potential problem drinkers. This information hopefully provided the test for hypothesis \#1 that the students at Chemawa need this particular kind of program more than just a health class unit.

It was determined that $4 / 5$ of the students tested at Chemawa have alcoholic relatives, and 12 of the students specifically stated that alcohol was a problem before coming to Chemawa. Four fifths of those tested drink and only $1 / 5$ abstain whlle attending Chemawa, even though the laws of the state and the rules of the school strongly forbid drinking. Five of the students even mentioned drinking as much or more at Chemawa than at home.

The Ifterature review showed that the average student in the United States drank for the first time at age 13-14 with their parents. The median age of starting to drink among the Chemawa students interviewed was 13 and among boys, 11 . Most of the students drank the first time with friends or in the case of the "drinkers" (1.e. those who had been 
KEY TO ABBREVIATIONS

USED IN TABLE 2

1 Tribe

2 Home state (Ak Alaska, Wn Washington, Id Idaho, Or Oregon)

3 Sex

4 Class

5 Drinker, "D", "D*"

6 Employment at CAEC (S Security, V Volunteer)

7 Abstainer, "A"

8 Alcoholic Relative, "AR"

9 Age at first drink

10 Who with at first drink (F friend, P parent, B brother, $S$ sister, ( cousin)

11 Drinking problem before coming to Chemawa

12 Drinks same or more here

13 Number of programs used 
TABLE 2

DEMOGRAPHIC CHARACTERISTICS BY CASE

\begin{tabular}{|c|c|c|c|c|c|c|c|c|c|c|c|c|}
\hline & 1 & 2 & 3 & 4 & 5 & 6 & 7 & 8 & 9 & 10 & 11 & 12 \\
\hline 1 & Eskimo & (Ak) & $\mathrm{F}$ & $\mathrm{Jr}$ & & & & $\mathbf{A R}$ & 16 & $\mathbf{F}$ & & $\mathrm{y}$ \\
\hline 2 & Eskimo & (Ak) & $\mathbf{M}$ & $\mathrm{Sr}$ & & & & & 15 & $\mathrm{~F}$ & & $y$ \\
\hline 3 & Eskimo & (Ak) & $\mathbf{F}$ & Sr & & & & $\mathrm{AR}$ & 16 & F & & $\mathbf{y}$ \\
\hline 4 & Eskimo & (Ak) & $\mathbf{F}$ & Fr & & $\mathbf{S}$ & $\mathbf{A}$ & & 15 & F & & \\
\hline 5 & Eskimo & (Ak) & $\mathbf{M}$ & $\mathrm{Jr}$ & $D^{*}$ & & & AR & 16 & $\mathbf{F}$ & y & \\
\hline 6 & Eskimo & (Ak) & $\mathbf{F}$ & So & & $\mathbf{S}$ & A & $\mathbf{A R}$ & - & & & \\
\hline 7 & Eskimo & (Ak) & $\mathbf{F}$ & So & & & & $\mathrm{AR}$ & 11 & $\mathbf{F}$ & & \\
\hline 8 & Eskimo & (Ak) & $\mathrm{F}$ & So & & $\mathbf{S}$ & A & & - & & & \\
\hline 9 & Eskimo & (Ak) & $\mathbf{M}$ & $\mathrm{Jr}$ & D & & & $\mathbf{A R}$ & 13 & $\mathbf{P}$ & & \\
\hline 10 & Eskimo & (Ak) & $\mathbf{F}$ & So & & $\mathrm{V}$ & & & 14 & F & & \\
\hline 11 & Eskimo & (Ak) & $\mathbf{F}$ & Fr & & & $\mathbf{A}$ & & 13 & $\mathbf{F}$ & & \\
\hline 12 & Eskimo & (Ak) & $\mathbf{M}$ & Fr & & & $\mathbf{A}$ & $\mathbf{A R}$ & 13 & $\mathbf{P}$ & & \\
\hline 13 & Athabaskan & (Ak) & $\mathbf{F}$ & $\mathrm{Jr}$ & & & & $\mathbf{A R}$ & 14 & $\mathbf{F}$ & & $y$ \\
\hline 14 & Athabaskan & (Ak) & $\mathbf{M}$ & Sr & D & $\mathrm{V}$ & & $\mathbf{A R}$ & 14 & $\mathbf{F}$. & & \\
\hline 15 & Athabaskan & (Ak) & $\mathbf{M}$ & So & D & $\mathbf{S}$ & & & 8 & B & & \\
\hline 16 & Athabaskan & (Ak) & $\mathbf{M}$ & Fr & & $\mathbf{s}$ & $\mathbf{A}$ & $\mathbf{A R}$ & 6 & $\mathbf{P}$ & & \\
\hline 17 & Athabaskan & (Ak) & $\mathbf{F}$ & $\mathrm{Jr}$ & & $\mathbf{V}$ & A & $\mathbf{A R}$ & 15 & F & & \\
\hline 18 & Aleut & (Ak) & $\mathbf{F}$ & Sr & & V & & $\mathrm{AR}$ & 15 & $\mathbf{F}$ & & \\
\hline 19 & Aleut & (Ak) & $\mathbf{M}$ & $\mathrm{Jr}$ & D & $\mathrm{V}$ & & $\mathbf{A R}$ & 10 & F & y & \\
\hline 20 & Aleut & (Ak) & $\mathbf{F}$ & $\mathbf{J r}$ & & $\mathbf{V}$ & $\mathbf{A}$ & AR & 17 & $\mathbf{P}$ & & \\
\hline 21 & T11nget & (Ak) & $\mathbf{M}$ & $\mathrm{Jr}$ & & $\mathrm{V}$ & A & AR & 12 & $\mathbf{F}$ & y & \\
\hline 22 & T1Inget & (Ak) & $\mathbf{F}$ & So & D & & & $\mathbf{A R}$ & 12 & B & $y$ & \\
\hline 23 & Tlinget & (Ak) & $\mathbf{M}$ & $\mathrm{Jr}$ & D & $\mathbf{S}$ & & AR & 9 & B & & \\
\hline 24 & Haida & (Ak) & $\mathbf{M}$ & So & & & & & 5 & B & & \\
\hline 25 & Lummi & (Wn) & $\mathbf{M}$ & $\mathrm{Jr}$ & D & $\mathbf{V}$ & & $\mathbf{A R}$ & 13 & $\mathrm{C}$ & y & \\
\hline 26 & Lumm1 & (Wn) & $\mathbf{M}$ & $\mathrm{Jr}$ & D & & & $\mathbf{A R}$ & 14 & $\mathbf{S}$ & & \\
\hline 27 & Muckleshoot & (Wn) & $\mathbf{M}$ & Sr & & & $\mathbf{A}$ & & - & & & \\
\hline 28 & Tulalip & (Wn) & $\mathbf{F}$ & Fr & & & & & 14 & F & & \\
\hline 29 & Tulalip & (Wn) & $\mathbf{F}$ & Sr & & & & AR & 15 & C & & \\
\hline 30 & Skokomish & (Wn) & $\mathbf{F}$ & Fr & & & & $\mathbf{A R}$ & 15 & F & & \\
\hline 31 & Suquamish & (Wn) & $\mathbf{M}$ & $\mathrm{Jr}$ & D & $\mathbf{V}$ & & $\mathbf{A R}$ & 11 & $\mathbf{s}$ & $\mathbf{y}$ & \\
\hline 32 & Quileute & (Wn) & $\mathbf{M}$ & Fr & D & & & $\mathbf{A R}$ & 12 & B & & \\
\hline 33 & Quileute & (Wn) & $\mathbf{M}$ & So & & & & AR & 11 & $\mathrm{C}$ & & \\
\hline 34 & Yakima & (Wn) & $\mathbf{M}$ & $\mathrm{Jr}$ & $D *$ & & & $\mathbf{A R}$ & 10 & C & $y$ & \\
\hline 35 & Yakima & (Wn) & $\mathbf{M}$ & $\mathrm{Jr}$ & & & & AR & 9 & $\mathbf{F}$ & & \\
\hline 36 & Yakima & (Wn) & $\mathbf{F}$ & $\mathrm{Jr}$ & D & & & AR & 12 & $\mathbf{s}$ & $y$ & \\
\hline 37 & Yakima & (Wn) & $\mathbf{F}$ & So & $D *$ & & & $\mathrm{AI}$ & 12 & $\mathrm{~F}$ & & \\
\hline 38 & Yakima & (Wn) & $\mathbf{M}$ & So & $D *$ & & & $\mathbf{A R}$ & 7 & $\mathbf{P}$ & & $\mathbf{y}$ \\
\hline 39 & Yakima & (Wn) & $\mathbf{F}$ & $\mathrm{Jr}$ & D & & & $\mathbf{A F}$ & 14 & $\mathbf{F}$ & y & \\
\hline 40 & YakIma & (Wn) & $\mathbf{M}$ & $\mathrm{Jr}$ & & & & $\mathrm{AR}$ & 13 & $\mathbf{F}$ & & \\
\hline 41 & Colville & (Wn) & $\mathbf{F}$ & Fr & D & & & AR & 10 & $\mathbf{F}$ & & \\
\hline 42 & Sauk/Sulattle & (Wn) & $\mathbf{F}$ & So & & & & AR & 5 & B & & \\
\hline 43 & Sauk/Sulattle & (Wn) & $\mathbf{F}$ & $\mathrm{Jr}$ & & & & AR & 5 & B & & \\
\hline 44 & Hoh & (Wn) & $\mathbf{F}$ & $\mathrm{Jr}$ & D & & & AR & 16 & B & & $\mathrm{y}$ \\
\hline 45 & Blackfeet & (Id) & $\mathbf{F}$ & Jr & D & & & $\mathbf{A R}$ & 14 & $\mathbf{F}$ & $y$ & \\
\hline 46 & Shoshone/Bannock & (Id) & $\mathbf{F}$ & So & & & & $\mathbf{A R}$ & 14 & $\mathrm{C}$ & & \\
\hline 47 & Shoshone/Bannock & (Id) & $\mathbf{F}$ & $\mathrm{Jr}$ & D & & & AR & 10 & B & $\mathbf{y}$ & \\
\hline 48 & Nez Perce & (Id) & $\mathbf{F}$ & $\mathrm{Jr}$ & & & & & 12 & $\mathbf{F}$ & & \\
\hline 49 & Nez Perce & (Id) & $\mathbf{M}$ & Sr & D & $\mathbf{V}$ & & $\mathbf{A R}$ & 3 & B & & \\
\hline & Warm Springs & (Or) & $\mathbf{F}$ & So & & & $\mathbf{A}$ & $\mathrm{AR}$ & 14 & $\mathbf{F}$ & & \\
\hline 51 & Warm Springs & (Or) & H & Fr & & & & $\mathrm{AR}$ & 7 & $\mathbf{P}$ & $\mathbf{y}$ & \\
\hline
\end{tabular}


brought in to the guest facility either this year, $D$, or last year, $D *$ for drinking), ,:with brothers and sisters. And it is interesting to note that youth drinking with their parents drank either at a much younger or much older age than those drinking with their friends ( 7 or 17 for parents and 14 for friends). Those starting with their brothers and sisters began the earliest of all (median age $=10$ ). Reasons given for drinking were:

$\begin{array}{lr}\text { to forget problems } & 17 \\ \text { boredom } & 14 \\ \text { to have fun } & 14 \\ \text { peer pressure } & 9 \\ \text { felt sad (a11 girls) } & 7 \\ \text { felt angry } & 2 \\ \text { speclal event } & 1\end{array}$

It is also interesting to examine those who considered themselves abstainers when interviewed (only three had never drank). 7/11 were female and $9 / 11$ were from Alaska. Most interesting was that $3 / 4$ of the males took great care to explain the reasons for their abstaining as though they needed to justify their oddity. One male was forced to drink at age 6 by his drunk mother and was revolted; one was recently arrested back home and chose to stay clean at Chemawa; and one was ralsed by white folks (the only one in the sample). The fourth male was an Eskimo freshman who came for his first visit with friends to CAEC the night of the interview.

According to the conclusions of the 1iterature review, these students have great potential for alcohol abuse or alcoholism. Even if those students who came to CAEC during the week were the only students at Chemawa School with these characteristics, there would be at least some students on campus with greater needs than can be met by 
conventional alcohol education classes. It is also significant that several students volunteered the information that they came to CAEC to gain Information and techniques for alcohol counseling in order to help others back home. It must be concluded, both from student perceptions and demographic data, that there is a need for a broader form of alcohol education and counseling at Chemawa. Therefore, hypothesis \#1 is accepted. There is a need at Chemawa for a special kind of alcohol education program.

\section{Hypothesis \#2}

Hypothesis \#2, that students would prefer this year's program over last year's was tested by question $\left.\right|_{2} 2$ on the interview schedule. The class breakdown was 7 Sentors, 22 Juniors, 13 Sophomores and 9 Freshmen. Due to the transfers in and out of boarding schools, elght of the upper classmen were not attending Chemawa last year and did not know about the program then. The remaining 32 upperclass students questioned were aware of the program, but 6 could not remember the program well enough to have an opinton on the changes seen from last year to this year. The investigator based the bet for improvements on the location and facility which is better this year than last. Students agreed and added their own thoughts on improvements:

$\begin{array}{lr}\text { better location } & 13 \\ \text { Increased space } & 11 \\ \text { no locks on the doors } & 5 \\ \text { more student participation } & 6 \\ \text { more and better counselors } & 4 \\ \text { better student volunteer pay } & 3 \\ \text { more student freedom } & 3 \\ \text { kinder treatment of drunk students } & 1 \\ \text { better system with the police } & 1 \\ \text { better organization } & 1\end{array}$


*No student interviewed sald that the program was better last year. $100 \%$ of those responding with definite evaluative answers reported that they felt this year's program to be better than last year's program. Thus hypothesis \#2 is accepted.

\section{Hypothesis \#3}

Hypothesis \#3 was that students interviewed would have ideas for change when asked their opinton. Two questions were designed to get at this information. Question \#6 asked if the students felt CAEC had been at all helpful to them. Two students stated that CAEC had been unhelpful (keeping too close an eye on their drinking activities on campus), and nine felt that CAEC had not yet been helpful even though $2 / 9$ had been to CAEC often already this year. Those responding that CAEC was indeed helpful to them stated the following reasons:

$\begin{array}{lr}\text { helped them learn about the effects of alcohol } & 15 \\ \text { helped them think before drinking or even abstain } & 12 \\ \text { provided counsellng, advice, Insight } & 11 \\ \text { helped them when they were drunk } & 5 \\ \text { helped a friend when he was drunk } & 2 \\ \text { helped them learn to help others } & 7 \\ \text { helped them understand their alcoholic relatives } & 2 \\ \text { provided a place to go to talk } & 7\end{array}$

Thus 2 students felt the center had been unhelpful, 40 helpful and 9 were unable to judge yet.

Question 非 was written to directly ask for opinions on change at CAEC. 22 students stated that they had no ideas even though $12 / 22$

*That only four students mentloned more and better counselors may be because they lacked famillarity with the staff which was all new this year except for the director. 
stated that they came In to CAEC at least twice a week and the researcher gave them much opportunity (even pleaded with them) to state. their Ideas for change. Three additional students felt that there should be no changes since CAEC was fine just as it was. The remainIng 26 students had 40 1deas for change, although very few coincided. Seven students felt that CAEC should try to get more students involved. Some other suggestions were to start more rap sessions in the dormitories; to create a better relationship with the dormitory staffs; to train students to help in emergencles; and to begin an activity program for students who drink frequently. Twenty one votes were cast for physical changes at CAEC (TV, radio, record player, food, better movies, more furniture and new rugs) and physical changes for the student volunteers (warmer and more colorful jackets, flashlights and walkie-talkies, and a name change reflective of their employed status). Three students mentioned allowing student volunteers more freedom and getting a blgger, nicer bullding, less like a holding facility. Three different students mentioned allowing student volunteers less freedom and creating a stronger holding facility. One student stated emphatically that this kind of education should take place at home. Although the students interviewed had many different, sometimes contradictory 1deas, only 26 had concrete Ideas for change, 22 no ideas and 3 wanted no change at CAEC. Combined with the results for question $\# 6$, it seems that students have interest in the center and can think of some minor changes that they would 1ike. However, the revolutionary overthrow of CAEC was not mentioned. It appears to the researcher that the results of these questions do not support hypothesis 
\#3 at least as strongly as was expected. Therefore, hypothesis \#3, that the students had Ideas for significant change, must be refected for lack of evidence.

\section{Hypothes 1s \#4}

Hypothesis \#4 was that the students brought in for drinking to the guest facllity would be more involved in the counseling program at CAEC than those not brought in. Students were Identified as "drinker" (D) In Table 2 if they answered affirmatively to the question \#5a, as to whether they had used the guest facllity. Once they stated that they had been brought into the CAEC for drinking, the investigator determined if this had happened this year (D) or last year ( $\left.D^{*}\right)$. It should be relterated that the students who did not rate as D may or may not drink while at Chemawa, but merely were not brought to the guest facility in the past two years. For the purposes of discussion, those who were not brought to CAEC for drinking violations were designated "non drinker"(ND). These NDs Include the total abstainers (A) and those who just were not caught.

It was discovered that the patterns of participation in CAEC programs were different for Ds and NDs. This was found to be true of all forms of participation at CAEC. The results are shown in Table 3. The Ds have greater program use in all areas than the NDs. Since the Ds Include more males (13 male, 8 female) than the NDs (10 male, 20 female), It may be thought that this difference is actually reflective of greater program use by males than females. However, upon analysis of program use by drinkers and nondrinkers controlling for sex, it can be seen that 
TABLE 3

"DRINKER" STATUS AND PROGRAM PARTICIPATION

BY TYPE OF PROGRAM

b. $f 11 m$

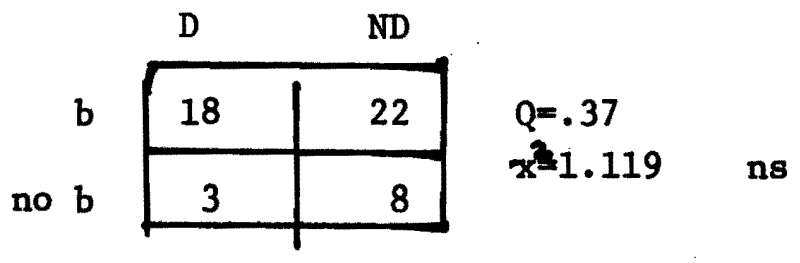

c. Information

\begin{tabular}{|c|c|c|c|}
\hline c & 17 & 20 & $Q=.36$ \\
\hline & 4 & 10 & $x=1.265$ \\
\hline
\end{tabular}

d. rapping

\begin{tabular}{|c|c|c|c|}
\hline d & 20 & 25 & $Q=.60$ \\
\hline no $d$ & 1 & 5 & \\
\hline
\end{tabular}

e. Individual

no e \begin{tabular}{|l|l|}
\hline 14 & 11 \\
\hline 7 & 19 \\
\hline
\end{tabular}$\quad \begin{aligned} & Q=.55 \\
& x^{2}=4.448\end{aligned} \quad p<.05$

f. discussion groups

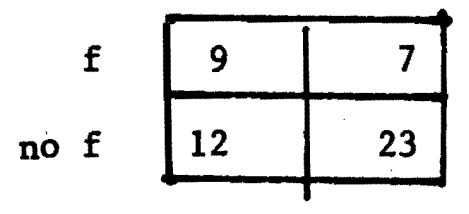

$Q=.42$

$x^{2}=2.187$ ns

g. group counseling

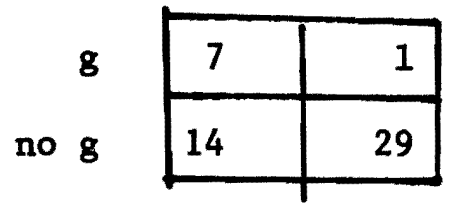

$$
\begin{aligned}
& Q=.87 \\
& x^{2}=8.406 \quad p<.01
\end{aligned}
$$

1. hang out

\begin{tabular}{l|l|l|}
1 & 15 & 16 \\
no 1 & $\begin{array}{l}Q=.37 \\
x^{2}=1.696\end{array} \quad$ ns \\
\cline { 2 - 3 } & 6 & 14
\end{tabular}

Sub-group analysis did not show different results for males and females. 
sex actually makes no difference. For instance, the analysis of question \#5e shows:

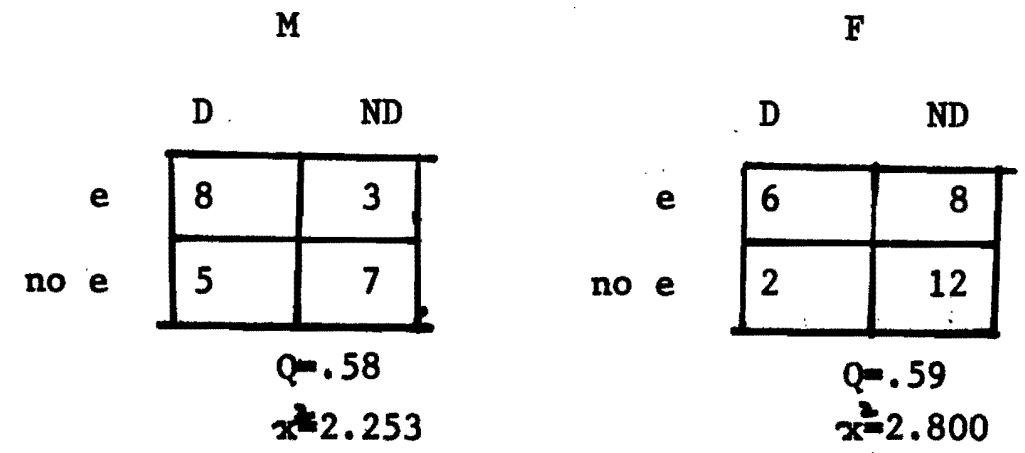

This same question showed significant difference between the Ds and NDs $\left(Q=.55, x^{2}=4.448, \mathrm{p}<.05\right)$.

With the questions directly relating to counseling, question \$5e (Individual counseling) and $\$ 5 g$ (group counseling), the results are as follows:
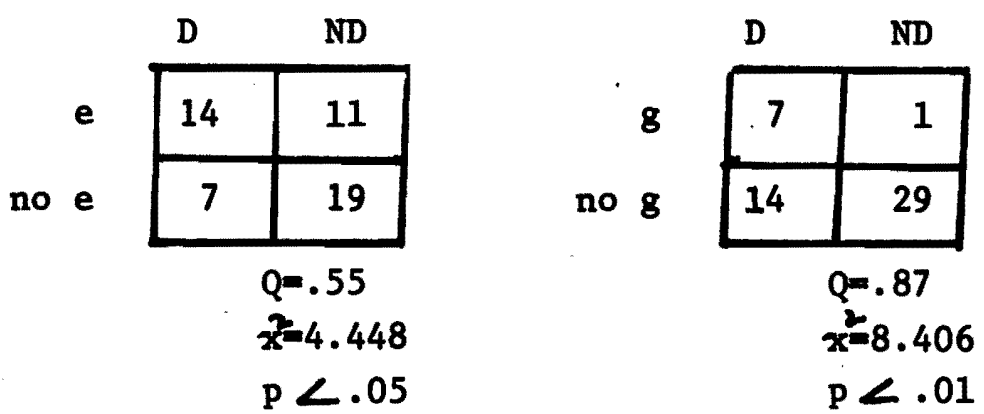

Program use in the areas relating to counseling is much greater among the Ds than among the NDs. Thus the students brought in for drinking violations are more involved in the counseling aspects of the program than those students not brought in. Th1s may appear obvious since the guest facility provides a point of reference between CAEC and problem drinkers, the staff is trained to deal with problem drinkers and those with identifled drinking problems should be in counseling. Partly this 
reflects the students on school probation for drinking at Chemawa who are required to attend CAEC. But it could fust as well have been found that the non-problem drinkers were the ones most involved in counseling since they come to CAEC on their own for various reasons and would seem to be more willing to get involved. That the "D's" who were brought in chose to stay and become the most involved is credit to the staff and program at CAEC. Thus CAEC tends to favor the problem drinkers but is not exclusively for them. Hypothesis $\$ 4$ is accepted.

Hypothes1s \#5

Hypothesis \#5, that the outreach of the CAEC staff is the most important means of advertising for the program, was tested through question \#3 ("How did you find out about CAEC?"). The results of this question were as follows:

$\begin{array}{lr}\text { friends told him } & 31 \\ \text { brought in for drinking } & 7 \\ \text { worked for security } & 7 \\ \text { told by dorm counselor } & 3 \\ \text { heard about on school announcements } & 1 \\ \text { found by accident } & 1 \\ \text { invited by CAEC counselor visiting dorm } & 1\end{array}$

total 51

Only one student can be sald to have been influenced by the direct outreach of the staff. Although most of the students $(42 / 51)$ have seen f1lms by the CAEC staff both at the center and in classes and dormitorles, only one student actually came to the center as a direct result of this kind of outreach. Films, then are not conclusively the most Important way of getting involved in the program. It may be that 
students who were not tested by this investigator have been helped by the outreach efforts of the staff, but for this study, hypothesis \#5 must be rejected.

\section{Hypothes18 \#6}

Hypothesis \#6 was that the CAEC program would be used more by the Northwest than by the Alaskan students. It appears that there are not b1g enough differences between the two groups of students to draw any strong conclusions. The differences seem to be greatest when comparing the Eskimos (Alaska) and the Yakima (Northwest), since the Aleuts (Alaska) and the Warm Springs (Northwest) and other tribes muddle the results when included. When limiting the comparison to these two small groups, It can be seen that demographically and active1y there are differences.

TABLE 4

BACKGROUND CHARACTERISTICS AND PROGRAM PARTICIPATION
COMPARISON OF ESRIMOS AND YAKIMAS

$\begin{array}{lll} & \begin{array}{c}\text { Eskimos } \\ \mathrm{n}=12\end{array} & \begin{array}{c}\text { Yakimas } \\ \mathrm{n}=7\end{array} \\ \begin{array}{l}\text { average age at } \\ \text { first drink }\end{array} & \text { age } 14 & \text { age } 11 \\ \begin{array}{l}\text { proportion who have } \\ \text { alcoholic relatives }\end{array} & 7 / 12 & 7 / 7 \\ \begin{array}{l}\text { proportion brought in } \\ \text { for drinking violation }\end{array} & 2 / 12 & 5 / 7 \\ \begin{array}{l}\text { average number of pro- } \\ \text { grams (b-1) used }\end{array} & 2 \text { programs } & 5 \text { programs }\end{array}$

The Yakimas tend to begin drinking at a younger age, are more 1ikely to have alcoholic relatives, use the entire program more, and be brought 
In for drinking violations than the Eskimos. But it cannot be said that the Northwest students use CAEC much more than the Alaskan students, because one Alaskan group, the Aleuts, have the greatest use of the program of any group. Thus hypothes1s \#6 must be rejected for lack of evidence.

In summary, then, the following hypotheses are accepted given the avallable data:

1) There is a need for a special kind of alcohol education program for this particular group of students;

2) The students intervlewed prefer this year's program over last year's program; and

4) Those students brought in for drinking violations are more Involved in the counseling aspects of the program than the other students.

The other hypotheses must be refected for lack of support:

3) The students interviewed will have 1deas for change;

5) The outreach of the CAEC staff is the most important means of advertising for the program; and

6) The CAEC program is used more by the Northwest students than by the Alaskan students. 
CHAPTER VI

CONCLUSIONS

In general it can be stated that the students' perceptions of the CAEC program are favorable. Those intervlewed for the most part felt comfortable with the staff, program and building and wanted to get Involved. Several students stated Informally that they were able to use some of the training last summer back home and that they find it easier to think before drinking. The student volunteers seemed to feel that CAEC belongs to them, and there is pride shown in being employed there. The students percelved the adult counselors as being approachable and sympathetic to their needs.

There are Indications also that CAEC as a whole is improving. This research was completed in November, 1972. Since that time, the physical facility has been renovated with wood paneling, wal1-to-wall carpeting, new windows and doors on the guest facility rooms, new office space, and the addition of a refrigerator and stove. The center has a new video $\mathrm{TV}$ on which can be shown campus video tapes and tapes made specially by the CAEC staff with new equipment. The student volunteers and interested students have been able to take trips to places as far away as Alaska and Salt Lake C1ty to appear on student alcohol panels. Group counseling has been enriched by a new staff member who owns several peace pipes which are used to develop Indian pride and spiritualism (to counteract the emptiness and meaninglessness filled by alcoho1). CAEC has also begun classes in karate which are immensely popular on the Chemawa campus. The 15 students in this groupi (80 are 
on the waiting 1ist) must train rigorously and are dropped from membership if they drink. This group encourages students to try alternative activities to drinking which provide prestige, skill and enjoyment at the same time. CAEC is visibly more involved with the rest of the Chemawa campus.

Likewlse, more students on campus are Involved with CAEC. There have been 50 student volunteers since the beginning of the year so that more students can be Involved. The average weekly attendance at the center has increased from 20 at the beginning of the year and 51 at the time of the study to 120 at the time of writing. The average number of students per weekend being brought to CAEC for drinking violations has been 6 . And probably most important is the low incldence this year of disclplinary drops due to drinking. Table 3 shows these figures for the past six years in order to emphasize the importance CAEC has had in helping some students remain at Chemawa School who might have been sent home in the past for problem drinking.

Many new areas are planned for the future at Chemawa. As question \#5h showed, there has been almost no contact with home reservations or alcoholism programs this year by CAEC staff members. But this summer, CAEC staff will visit elght areas in the Northwest where some Chemawa students come from (LaPush, Tulalip, Lumm1, Yakima, Omak, Warm Springs, Umatilla, and Lapwa1). All of the adult counselors will make the trips, and CAEC plans to tape any meetings. The Advisory Board secretary w111 arrange the meetings at these locations so that parents, school board members, tribal council members and tribal alcoholism counselors will all be able to meet with CAEC to provide input and develop summer or post- 
graduate alcohol counselor training for students who live in these areas and have the interest to learn more and help Indian people.

\section{Discussion of Refected Hypotheses}

Other changes planned for the next year may affect the acceptance of two hypotheses of this study. The rejection of hypothes1s \#3, that students interviewed would have significant ideas for change, may be different now since the interview was made early in the year. There may have been discontent that was not registered by the interview. The program was actually fairly new this year, and the students might not have thought much about 1t. Next year, CAEC hopes to be sensitive to student input for change and to get more students involved. Thus there may be opportunfty for a larger number of students, whose needs may be different, to make significant change in the CAEC program. The CAEC staff will try new forms of alcoholism counseling and will be decentra11zed as it expands its area of operation. Students w11l be closely consulted on these changes.

The decentralization of CAEC has implications for hypothesis \#5, that the outreach of the counselors was the most important advertising for CAEC, which was also rejected. Next year, five CAEC counselors will spend time in the five dormitories on campus, one assigned to each. Each counselor will have his own offlce at the assigned dormitory and will be responsible for the implementation of a dormitory based alcohol education program. The students in each dormitory will help to work out individual policies, within guidelines set by the main center program, in order to get more students involved in the overall program. This 
plan will allow students the opportunity of learning more about alcohol and drugs without needing to go to the center. Also CAEC hopes to begin alcoholism classes which students can take for credit in the regular academic program.

Need for Further Research

If more projects such as the Chemawa Alcohol Education Center are to be instituted at other boarding schools, there should be additional research done, not only of the student perceptions, but of the population to be served and of the long-range effectiveness of the program. Each boarding school would have a different population so that the needs would be different and the possible ways of running the alcohol education program would be different. Perhaps CAEC has shown that programs run well with student input and responsib1lity, all-Indian adult counselors, and a varlety of tasks and activities for the students of the school. These findings are, at best, exploratory in eliciting the thoughts of the students. But as Table 1 shows, CAEC has performed a service to the school in helping students to stay in school who previous1y would have been sent home for drinking.

Alcohol abuse among Indian youth is a problem. The previous study and review of the 11terature have amply demonstrated the extent of this problem to Indian people. Early intervention of schools through meaningful programs such as CAEC may help to lessen the problem. 


\section{BIBLIOGRAPHY}

Alexander, Norman, Jr., "Alcohol and Adolescent Rebellion," Social Forces 45:4 (June, 1967), 542-50.

Alexander, Norman, Jr. and Ernest Campbell, "Peer Influence on Adolescent Drinking," Quarter1y Journal of Studies of Alcoho1 28:3 (September, 1967), 444-53.

Bacon, Margaret, and Mary Brush Jones, Teen-Age Drinking. New York: Thomas Y. Crowe11, 1968.

Berreman, Gerald, "Drinking Patterns of the Aleuts," QJSA 17:3 (September, 1956), 503-14.

Blacker, Edward, Harold Demore, Jr., and Howard Freeman, "Drinking Behavior of Delinquent Boys," QJSA 26:2 (June, 1965), 223-37.

Blane, Howard, Marjorle Hill and Elllot Brown, "Allenation, SelfEsteem and Attitudes Toward Drinking in High-School Students," QJSA 29:2 (June, 1968), 350-4.

Boyce, George, Alcohol and American Indian Students. Washington, D.C.: U.S. Department of Intertor, 1965.

Cain, Arthur, Young People and Drinking: The Use and Abuse of Beverage Alcohol. New York: John Day Co., 1963.

Chappe11, Matthew, Use of Alcoholic Beverages Among High School Students. New York: The Mrs. John S. Sheppard Foundation, Inc., 1953.

Dav1d, Lester, "The Problem of Teenage Drinking," Good Housekeeping Vol. 155 (November, 1962), 73,

Demore, Harold, Jr., "Implications From Research on Adolescent Drinking," Alcohol Education Conference Proceedings of the Secretary's Committee on Alcoholism. Washington, D.C.: U.S. Department of Health, Education and Welfare, March 29, 1966.

Drilling, Vern, Problems with Alcohol Among Urban Indians in Minneapolis. Minneapolis, Minn.: Training Center for Community Programs of the University of Minnesota, August, 1970.

Forslund, Morris and Thomas Gustafson, "Alcohol and H1gh-Schoolers." The Bulletin of the National Assoctation of Secondary School Principals 53:338 (September, 1969), 52-9:

Garlie, Norman, "Characterist1cs of Teenagers with Alcohol Related Problems." FaD dissertation, University of Utah, 1971. 
Globett1, Gerald, "The Use of Beverage Alcohol by Youth In an Abstinence Setting," Journal of School Health, 39:3 (March, 1969), 179-83.

Globett1, Gerald and Danny Harrison, "Attitudes of High School Students Toward Alcohol Education," The Journal of Schoo1 Health 40:1 (January, 1970), 36-9.

Graves, Theodore, "Acculturation, Access, and Alcohol in a TriEthnic Community," Amerlcan Anthropologist 69:3-4 (JuneAugust, 1967), 306-19.

Hirsh, Joseph, Alcohol Education: A Guldebook for Teachers, New York: Henry Schuman Publishers, 1952.

Jessors, Richard, Theodore Graves, Robert Hansen and Shirley Jessor, Soclety, Personality and Deviant Behavior: A Study of a TriEthnic Community. New York: Holt, Rinehart, and Winston, 1968.

Jessor, RIchard, H. Boutourline Young, Ellzabeth Young and Gino Tes1, "Percelved Opportunity, Allenation, and Drinking Behavior Among Italian and American Youth," Journal of Personality and Social Psychology 15:3 (July, 1970), 215-22.

Kane, Robert, and Elizabeth Patterson; "Drinking Attitudes and Behavior of High-School Students in Kentucky," QJSA 33:3 (September, 1972), 635-46.

Kearney, Thomas, and Clarence Taylor, "EmotIonally Disturbed Adolescents with Alcoholic Parents," Acts Paedopsychiatrica 36:6-7 (1969), 215-21.

Landers, Ann, "Booze and You," Readers' Digest 84:503 (March, 1964), 133-6.

Lang, Barbara, "When Teenagers Start to Drink," New York Times (July 19, 1964), 47+.

Lemert, Edwin, Alcohol and the Northwest Coast Indians. Berkeley, California: University of California Press, 1954.

Lucla, Salvatore, Alcohol and Civilization. New York: McGraw-H111 Book Co., Inc., 1963.

MacKay, James, "Alcohol, Alcohollsm, and Youth," Socla1 Work 10:1 (January, 1965), 75-80.

"Clinical Observations on Adolescent Problem Drinkers," QJSA 22:1 (March, 1961), 124-34. 
Mackay, James, Derek PhIllips andForbes Bryce, "Drinking Behavior Among Teen-Agers: A Comparison of Institutionalized and NonInstitutionalized Youth," Journal of Health and Soclal Behavior 8:1 (March, 1967), 46-54.

Maddox, George, "HIgh-School Student DrinkIng Behavior: Incidental Information From two National Surveys," QJSA 25:2 (June, 1964), 339-47.

, "Research Relating to Alcohol Education: A Review and Some Suggestions," Alcoho1 Education in Inst1tutions of H1gher Learning. B1loxi, M1ss.: Mississippi State and U. S. Department of HEW, March 26-8, 1963.

Maddox, George and Berode McCa11, Drinking Among Teen-Agers: A Sociological Interpretation of Alcohol Use by H1gh School Students. New Brunswlck, N.J.: Rutgers Center of Alcohol Studies, 1964.

McCarthy, Raymond, Teen-Agers and Alcohol: A Handbook for the Educator. New Haven, Conn.: Yale Center of Alcohol Studies, 1956.

McCarthy, Raymond and Edgar Douglass, Alcohol and Social Responslbility: A New Educational Approach. New York: Thomas Y. Crowe11, Co., 1949 .

McCluggage, Marston, et. al., Attitudes of H1gh School Students Toward the Use of Alcoholic Beverages. A study made by the Department of Soc1ology and Anthropology, University of Kansas, for the Mrs. John S. Sheppard Foundation, Inc., New York, 1956.

Mullin, Laurence, "Alcohol Education: The School's Responsibility," Journal of School Health 38:8 (1968), 518-22.

Nelson, Dale, Drinking and Student Understanding of Alcohol and Alcoholism in Selected High Schools of Utah. Logan, Utah: Utah State University, January 1, 1967.

Oppenhe1m, Garret, "Teenage Drinking Can Spell D1saster," Parents 36:10 (October, 1961), 80-1+.

Oregon State Liquor Control Commission, Handbook for Alcohol Education in Oregon. Salem, Ore.: Oregon State Department of Education, March, 1955.

Oregon State Mental Health Division, Teen-Age Drinking In Oregon 1962. Portland, Ore.: Oregon State Mental Health Division, 1965. 
Pearce, Janice and H. Dean Garrett, "A Comparison of the Drinking Behavior of Delinquent Versus Non-Delinquent Youth in the States of Idaho and Utah," The Journal of School Health 40:3 (March, 1970), 131-5.

Pittman, David and Charles Snyder, Soclety, Culture and Drinking Patterns. New York: John Wiley and Sons, Inc., 1962.

Sanders, William and Winfred Bloomberg, Teaching About Alcohol in Connecticut Schools. Connecticut State Department of Mental Health and Department of Education, Report Bulletin \#99, 1966.

Straus, Robert and Seldon Bacon, Drinking in College. New Haven, Conn.: Yale University Press, 1953.

United States Department of Health, Education and Welfare, First Special Report to the U.S. Congress on Alcohol and Health, Washington, D. C.: U. S. Government Printing Office, December, 1971.

Welr, William, "A Program of Alcohol Education and Counseling for High School Students With and Without a Family Alcohol Problem." PtiD dissertation, University of North Dakota, 1967.

- Needs of Students with an Alcohol Problem In Their Family. Washington, D. C.: American Personnel and Guidance Association, Apr11, 1968.

Wilson, Sloan, "Should You Offer Teen-Agers Drinks In Your Home?" Readers' Digest 86:516 (Apr11, 1965), 100-2. 
APPENDIX 
CAEC INTERVIEW SCHEDULE

1. name, tribe, where from

2. class if upper classman:

a. were you at Chemawa last year?

b. do you remember last year's program?

c. did you use 1t? how?

d. have you seen changes this year? what? do they seem to be Improvements?

3. how did you find out about CAEC?

4. how often have you been at CAEC?

5. how have you used CAEC?

a. guest facility

b. films

c. Information

d. Informal Individual rapping

e. Individual counseling

f. discussion group (rapping)

g. therapy group

h. contact with home

1. hang out (refuge)

j. other

6. has CAEC been helpful to you? what most? least?

7. do you have any ideas for Improvement? things that you'd 11ke to see changed? 
8. (Optional) Personal information

a. do you have any alcoholic relatives?

b. when did you first drink?

c. who did you first drink with?

d. was drinking ever a problem before coming to school?

e. do you drink as much or more here than back home?

f. what makes you drink while at school?

1) adjustment from treated as adult to child

2) peer group pressure

3) forget problems

4) feel angry

5) feel sad

6) other 
ADMISSION TO CHEMAWA SCHOOL

The following Information about Chemawa and the admission process Is for the use of BIA Agency social workers, education specialists and others who will be preparing and submitting applications for students to enter Chemawa Indian High School.

\section{A. GENERAL INPORMATION}

Chemawa is an accredited school, with primary emphasis on preparing the student to exercise his own options upon graduation, whether these options be academic or vocational in nature. Chemawa essentially functions as a learning center rather than an institution that serves chronic behavioral and/or emotional difficulties. Its educational and dormttory living programs are designed to provide opportunities for students to ralse their academic achievement to the national level and to achleve this goal through the speclalized resources available at Chemawa. Whenever local communtty resources and schools near the student's home can better meet the educational and behavioral needs of a student, these should be used.

Chemawa must give the highest priority to parents' expectations that their children will have a positive living and learning experlence while at school. Students who apply to Chemawa must, therefore, assume a great deal of personal commitment, not only for class attendance but for honest effort in classes, particlpating in school activities, refraining from behavior harmful to himself or others, and for being a responsible member of the Chemawa community. Much student preparation must take place in the agency's application process with prospective 
students if parents and school expectations are to be understood. This is particularly true in view of the fact that the majorlty of applicatlons reflect a history of fallure in the public school system and frustration with public school programs and staff. Included in this group are Individuals whose living circumstances have been continually disrupted by alcoholism, parental separations and physical abuse. For these youngsters Internal controls are not developed and they need a school where spectal help can be given in the classroom, dormitories and through spectallzed programs, 1.e. CAEC, group counseling, psychlatric services.

Chemawa staff has a commitment to afford students the opportunity and assistance necessary to achleve their educational and behavioral goals; Chemawa, however, cannot be all things to all people, nor can it offer programs to ameliorate the total range of educational and social needs to be found in the adolescent Indlan population who need assistance.

The responsibility for decisions concerning admission and retention of students, In view of their needs and the capabilities of Chemawa to meet their needs must, therefore, rest with the superintendent and his staff.

B. CRITERIA

Certain eligibility requirements are specified in the Bureau of Indian Affairs manual for admission to a boarding school. Applicants must have:

1. Membership in a federally-recognized tribe or group 
2. At least one-quarter degree or more Indian ancestry

Priority is afforded students living on or near trust land served In the Portland area.

In addition to the above, students must meet one or more of the following to be eligible for admission:

1. Educational criteria

a. Those for whom a public or Federal day school ts not available.

b. Those who need special or other Individual educational planning will be considered on an Individual basis as programs are avallable and can be individually tailored at the school.

2. Social Criteria.

a. Those who are rejected or neglected for whom no suitable plan for secondary education can be developed.

b. Those who belong to large families with no suitable home and whose separation from each other is deemed undesirable for success in achieving educational growth.

c. Those whose behavior problems are too difficult for solution by their families or through existing community facilities and who can benefit from the structured environment of Chemawa without interfering with or Impeding the educational or social progress of other students.

d. Those whose health or proper care is jeopardized by 111ness of other members of the family. 
3. Readmission Criteria

a. A preadmission contract may be established with a student who has been a disciplinary dismissal from Chemawa. The agreement w111 be established between the re-applicant and the school by the Admissions Committee, and w111 specify goals for the student to accomplish before he come back to Chemawa. Each agreement will be tallored to the circumstances of the individual, will be based on our knowledge of the student, and will be designed to include achievable goals within a set time limit. This allows the motivated re-applicant the opportunity to prove to himself that he can exercise control of himself and achieve a meaningful goal as a result of his own actions.

b. Students who re-apply following disciplinary release from Chemawa and whose history indicates a rejection of efforts to control or modify their behavior may be admitted on probation. These students may or may not have been involved In a pre-admission contract. Probation provides the student with a reasonable opportunity to demonstrate his ability and willingness to adjust to Chemawa's structured environment after he returns to Chemawa.

c. Students in unexcused absence status for 10 consecutive school days must re-apply for admission. During the 10day period the agency and/or parents will be reminded that a letter of re-application explaining the unexcused absence must be written to the superintendent by the student in 
order to consider him for re-admission. (Chemawa staff will notify the agency and/or parents of the unexcused absence of the student within 48 hours after the stu-' dent's placement in this status.)

The student school history and social summary are the key dociments in the development of plans for students; as such, they must specify under which criteria admission Is sought and they must be accurate, complete and frank. The interests of the prospective student cannot be served if vital data are omitted concerning his functionIng in his own environment. Incomplete applications, Including those lacking high school transcripts, soclal summarles, or agreement forms will not be approved. If not completed in time, admission may be refused for the current school term.

Prepared by: Admissions Committee, Chemawa Indian School 
GUIDELINES FOR CHEMAWA

ALCOHOLISM EDUCATION CENTER

C.A.E.C.

\section{INTRODUCTION :}

Chemawa Alcoholism Education Center is an organization established to assist students who are interested in or may be having drinking or drug problems. Its function is not to punish or fix blame. All students are entitled to its services.

The student volunteer $1 \mathrm{~s}$ first of all a concerned Chemawa Student. He is NOT a policeman. He offers an alternative to enforcement services and the Juvenile Detention House. The student volunteer is an important aspect of C.A.E.C. "Out-Reach" Program.

OPERATIONAL CODE \& GUIDELINES:

1. The student volunteer shares, refers, accompanies, or secures transportation through Security to the Health Center for any student who is (a) experiencing difficulty in breathing, (b) unconscious, (c) Injured, (d) threatened sulclde, (e) having selzures or (f) has ingested or infected an unknown substance. (Bring in the last case, any p111s, containers, needles, plpes, etc., that may be avallable for identification lof the material).

2. Students involved in drinking behavior will be handled on an Individual basis so far as possible. The student volunteer shall make the resources of C.A.E.C. avallable or may refer the student to his or her dormitory. In elther case, C.A.E.C. or the dormitory is to be advised of the action taken.

3. In the event that a student is so Intoxicated that he is of 
danger to himself and others, or property, Campus Security Is to be notified immediately.

4. The student volunteer will be provided with a notebook at C.A.E.C. prior to his or her duty hours. All incldents should be noted and logged in the notebook, including (a) date, (b) time, (c) location, (d) students name, (e) brief description of observations and action taken. All notebooks shall be returned to C.A.E.C. at the shift end, and all reports filed under the date in a central loose leaf binder.

5. All matters pertaining to the student volunteer's activities with C.A.E.C., Its staff and clientele shall be held in confidence by the volunteer. Releasing confidential information shall be cause for Immediate termination.

6. Disclplinary action will follow if a student volunteer is found to be involved in drinking or drug activities.

(a) Immediate termination will result if the volunteer is found to be drinking or taking drugs while on the job.

(b) Two-week suspension will result if the volunteer is found to be drinking or taking drugs during off duty hours.

\section{Prepared by:}

Stephen LaBuff, Director, Chemawa Alcohol Education Center 
CHEMAWA ALCOHOLISM EDUCATION CENTER

STRUCTURE \& FUNCTION

SCHOOL YEAR 72-73

INTRODUCTION

The contents outlined below shall serve as a guide for the CAEC profect. It 18 directed to both staff and the program.

OUTREACH POLICY

1. To more efficiently extend the CAEC program to the student population, two counselors shall be assigned to coordinate the "Outreach Project." These personnel shall work in close confunction with CAEC Student Volunteers on the campus, at student activities and in the dormitories. It shall be the function of the above to:

(a) Inform the student population of the CAEC program and its resources.

(b) Counsel with individual students and groups regarding alcohol and drug problems at Chemawa and in Indian communities.

(c) Check Individual students and groups for use of alcohol and drug products.

(d) Make referrals to CAEC based counselors of students requiring follow-up, or long-term counseling

(e) Coordinate in-dormitory education programs for guldance staff and student groups.

(f) Submit a brief written narrative report of each day's activities at the end of the shift. 
FACILITY BASED POLICY

1. The Chemawa Alcoholism Education Center is the central office for the project. It coordinates the field services, has facilities for group and individual counseling, and a detoxification unit. Two counselors will be assigned at the Center on a full-time basis. It shall be the function of the above to:

(a) Provide extensive individual and group counseling to students experiencing a drinking or drug problem. Comprehensive records of actions taken with Individuals Involved shall be maintained.

(b) Provide supervision of the detoxification unit.

(c) Make referrals to the Health Center, JDH or other appropriate agencles of students requiring care beyond the scope of CAEC.

(d) Sponsor alcohol education program for students and staff at CAEC.

OTHER AGENCY RELATIONS

1. Comprehensive care required that other related agencles and resources become involved in the work of the Chemawa Alcohollam Education Center program. To Insure smooth relations with the above, the following are set forth as guldelines:

HEALTH CENTER

(a) Final responsibility for coordination of care of a client cannot be shared. In the last analysis the student must be either In the care of CAEC or the Chemawa School Health Center. 
(b) Any CAEC allied person shall refer, accompany or secure transportation through Security directly to the Health Center for a student who is (1) experiencing difficulty in breathing, (2) unconsclous, (3) injured, (4) threatened sulcide, (5) having seizures or (6) has ingested an unknown substance. (In the last case bring any p1lls, containers, needles, plpes, etc., that may be avallable for the Identification of the material).

(c) Referrals to the psychlatrist, avallable through the Health Center should be made through Mrs. Irma Newton. Referrals should be accompanied by a written explanation of the ctrcumstances precipitating the request. The student should be counseled in advance of the referral as to the reasons and anticipated outcomes of the consultation.

(d) Requests for training are encouraged and should be made through the Health Center Service Unft Director.

\section{GUIDANCE}

(a) CAEC w111 insure that the intoxicated student who has been a guest of the Center is sober before he or she is returned to the dormitory. A student volunteer should then assist the student back to the dormitory and remain with him or her until the student has been returned to his room and has gone to bed. (b) When students who have been referred to the Center by Dormitory Staff are ready to return to the dormitory, the dormitory will be called and told that the student 1s leaving the Center and is returning to the dormitory. 
(c) A CAEC staff member will call the dormitories by 10:00

P.M. on weekdays and 11:00 P.M. on weekends to inform dormitory staff of students who are working as volunteers and those who are guests.

(d) CAEC staff would like to conduct group counseling and Informational meetings in the dormitorles in regard to "alcohol and drug abuse."

(e) CAEC staff w11l spend time in the dormitories to establish better working relationships with dormitory staff and gain a better understanding of dormitory programs. The staff of CAEC w111 serve as an active member in the dormitory Resource Team to help gain an understanding of the overall dynamics of Individual students referred to the Center. They w111 ald other members of Resource Team in understanding and helping those students who are being alded through the CAEC program.

\section{SECURITY}

(a) CAEC will provide assistance to Security, as well as other staff in working with students who are intoxicated. CAEC volunteers on duty will talk with such students, encouraging them to go to the dorm and to bed or to go to the CAEC Center. Security will assist the Student Volunteers in dealing with the Chemawa student as the need arises. Security will work closely with student campus patrol and CAEC for more effective student control over student behavior; maintaining good on and off campus student vigilance over 1lquor, drugs, and other abuses which may be harmful 
to students.

(b) The Security and Safety Department may request assistance

from local, state, and federal law enforcement agencies as needed.

(c) Security is Immediately available to all night personnel by means of telephone or electronic devices and keeps in close contact with the dormitory and CAEC personnel throughout the evening, giving support and assistance as needed.

Prepared by:

Stephen LaBuff, Director, Chemawa Alcohol Education Center 